\title{
Penjurian Sastra di Masa Kebiasaan Baru
}

\section{Zulkifli Makmur \\ Sekolah Tinggi Darud Dakwah wal Irsyad Kota Makassar}

zulkifli.makmur@mail.ugm.ac.id

Abstrak

Artikel ini merupakan hasil pelaporan penjurian di Festival SINORA OCE (Seni dan Olahraga Online Competition) 2020 BEM POLITEKKES KEMENKES Makassar. Peserta terdiri atas dua orang. Peserta mengirimkan karyanya dalam bentuk skrip dan video. Peserta selain membuat puisi juga diminta membuatkan video deklamasinya, berikut dengan video dan musik ilustrasinya.

\section{Latar Belakang}

Untuk pertama kalinya di sebuah event lomba saya diberi tanggungjawab menilai cipta baca puisi dimana penulis harus berperan sebagai penulis puisi, pembaca puisi, sekaligus pembuat video visual dan ilustrasi pembacaan puisi (Makmur, Z; 2020). Menurut saya, kompetitor harus memiliki keterampilan multi tasking untuk menjadi juara di festival ini (Alwi, A. M. S., Arsyam, M., Sainuddin, I. H., S, \& Makmur, Z. 2020).

Oleh karena itu, sebelum mempresentasikan penilaian saya, di kesempatan ini saya harus salut dulu sama peserta lomba yang berhasil mengikuti lomba ini (Makmur, Z., \& Sainuddin, I. H., S. 2020). Kalian memiliki kemampuan lebih yang bukan hanya dituntut sebagai penyair, tetapi kalian juga harus menjadi editor, dan pendeklamasi puisi kalian sendiri (Makmur, Z; 2020). Kesulitan sebagai juri disini tentunya pasti akan kompleks (Makmur, Z; 2020). Saya tidak hanya mengamati hubungan tiap kata, hubungan antar baris, estetika penulisan, dan metofora yang terbangun di dalam puisi (Makmur, Z., Sainuddin, I. H., S, Arsyam, M., \& HERIANTO, H; 2020), tetapi juga saya harus menyimak deliveri peserta dalam mengekspresikan puisinya, terlebih lagi saya harus mendengar musik pengiring yang dijadikan ilustrasi dalam pembacaannya, sampai visualisasinya di dalam video (Makmur, Z 2020). Sebab, salah satu peserta ada yang menggunakan visualisasi foto-foto penanganan Covid-19 yang tentunya semua itu adalah bagian dari upaya peserta menciptakan drama yang menggugah. Inilah yang membuat karya-karya peserta cipta baca puisi SINORA OCE 2020 menjadi istimewa (HERIANTO, H., Jusmiana, A., Jusmawati, J., \& Makmur, Z; 2020).

Karena ini adalah lomba maka saya memiliki penilaian tersendiri dalam menentukan siapa pemenangnya, tetapi di luar dari lomba ini semua peserta lomba cipta baca puisi ini adalah adik-adik yang hebat (Alwi, A. M. S., Arsyam, M., Sainuddin, I. H., S, \& Makmur, Z; 2020).

\section{Hasil dan Penutup}

Peserta pertama, Evi Andriani Susanti. Peserta membaca puisinya dengan baik. Meskipun rasa canggungnya tidak bisa ditutupi tetapi deliverinya baik. Puisinya berisi kata-kata pemberi semangat kepada petugas medis yang saat ini berjibaku menangani pasien-pasien COVID-19. Hanya saja di dalam videonya, peserta tidak mengatur volume musik ilustrasi sehingga deklamasinya banyak tertutupi oleh musik. Di penulisan peserta tidak fokus pada pemilihan kata, sehingga puisinya belum menemukan kebaruan. Kesesuaian tema saya beri nilai 8. Daya tarik bahasa saya beri nilai 12. Kedalaman makna saya beri nilai 5. Penghayatan saya scoring 15. Pengucapan 11. Dan gesture saya beri 9. Jadi total penilaian saya untuk Evi Andriani Susanti yaitu 60. 
Peserta kedua Sri Selviana Novitasari. Peserta membaca puisinya dengan penghayatan yang tinggi. Suaranya cukup lantang. Videonya memiliki ilustrasi video dan gambar yang dramatik. Sayangnya, Sri mengambil latar yang kurang tematik, yaitu dinding yang keluar dari framing puisi. Lain kali Sri cari background yang tepat ya biar tidak mengganggu penontonmu menyaksikan videomu. Dari Kesesuaian tema saya beri nilai 8. Daya tarik bahasa saya beri 15. Kedalaman makna saya kasih 7. Penghayatan saya nilai 18. Pengucapan 15. Dan gesture saya score 11. Total scorenya 74.

Selamat Sri.

Terima Kasih

Makassar 22 oktober 2020

\section{Referensi}

Makmur, Z. (2020, October 17). Film Snowden; antara Paranoia dan Tipuan-Tipuan Klasik Amerika. https://doi.org/10.31219/osf.io/9hgc7

Makmur, Z., \& Sainuddin, I. H., S. (2020, October 10). Karenang di atas Canon (sebuah Apresiasi). https://doi.org/10.31219/osf.io/k6r94

Makmur, Z. (2020, October 13). Paradoks Hubungan antara Manusia, Lingkungan, dan Sains dalam Enam Sekuel Film Final Destination (Sebuah Pendekatan Self-Deconstruction). https://doi.org/10.31219/osf.io/eacgs

Makmur, Z. (2020, September 10). Dekonstruksi puisi "The Divine Comedy" karya Dante Alighieri dalam Novel "Inferno" karya Dan Brown. https://doi.org/10.31219/osf.io/cwypx

HERIANTO, H., Jusmiana, A., Jusmawati, J., \& Makmur, Z. (2020, June 21). Comparing Learningat-home Activities of Students Living in Cities and Those Living in Villages during the Covid-19 Pandemic. https://doi.org/10.31219/osf.io/m4x9b

Alwi, A. M. S., Arsyam, M., Sainuddin, I. H., S, \& Makmur, Z. (2020, August 18). PELESTARIAN LINGKUNGAN SEBAGAI IMPLEMETASI DAKWAH BI AL-HAL DAN WUJUD KESADARAN MASYARAKAT. https://doi.org/10.31219/osf.io/vf6qm

Makmur, Z. (2020, August 2). Membangun Kesadaran Apokaliptik melalui Sastra di Masa Pandemi. https://doi.org/10.31219/osf.io/utvyk

Makmur, Z., Sainuddin, I. H., S, Arsyam, M., \& HERIANTO, H. (2020, July 4). Paradoxical Relationship between Humans, the Environment, And Science in Final Destination (Movies). https://doi.org/10.31219/osf.io/ukr4q 